\title{
The Central Characteristics of Successful ESL/EFL Teachers
}

\author{
Khalid Al-Seghayer \\ Al Imam Mohammad Ibn Saud Islamic University, Riyadh, Saudi Arabia
}

\begin{abstract}
Achieving optimal success in teaching English as a second language (ESL) or English as a foreign language (EFL) requires teachers to demonstrate varying essential characteristics that consist of several underlying and interacting constructs. The purpose of this article is to orient the reader and succinctly identify the key variables that lead ESL/EFL teachers to distinctive success. It clearly delineates the characteristics of successful ESL/EFL teachers embedded within five central dimensions, along with their underlying structures. It also provides common taxonomies of successful EFL teachers' attributes without burdening the reader with unnecessary detail concerning the many other validated attributes associated with ESL/EFL teachers' salient attributions of success. To this end, this discussion contributes to a theoretical understanding of the development of successful ESL/EFL teachers and to improved knowledge of the key characteristics of successful ESL/EFL teachers.
\end{abstract}

Index Terms - characteristics of successful ESL/EFL teachers, cognitive knowledge, content knowledge, English language proficiency, personality traits, key related variables

\section{INTRODUCTION}

Teachers are the key figures in the English-language learning process. Teachers fuel their students' interests and efforts, or tackle the lack thereof, making their influence fundamental to students' progress. In this way, teachers of English as a foreign language (EFL) can have a far-reaching, long-term, and suggestive impact on their students' EFL learning journeys.

To achieve success in teaching English - that is, to guide students to successful acquisition - EFL teachers have to be aware of and possess certain essential competencies with broad appeal across a range of domains. They also need to consider and engage with crucial factors in the language-learning and teaching literature and, above all, understand how students learn EFL. Unfortunately, the EFL field has yet to successfully frame the discourse and debate surrounding the key characteristics of successful EFL teachers. The literature still fails to articulate a values-driven, principles-based framework informed by research-based practices and data concerning the outstanding characteristics of successful EFL teachers. To address this gap, this article delineates the identifiable professional characteristics of successful EFL teachers within the ESL/EFL teaching community.

Successful ESL/EFL teachers, as Figure 1 displays, (a) display explicit awareness of the cognitive knowledge dimension of language teaching; (b) develop profound knowledge of related content, that is, disciplinary knowledge, pedagogical knowledge, and technological pedagogical knowledge; (c) attain a high level of English language proficiency; (d) possess certain unique personality traits; and (f) possess other related key variables.

The first section of this article explores successful ESL/EFL teachers' cognitive knowledge by revealing the mental lives/structures encompassing these teachers' beliefs as well as other aspects of the ways in which they label the cognitive knowledge of pedagogical and learning principles that guide their discursive practices. The second section discusses the content knowledge of successful ESL/EFL teachers as well as the significant need to organize this knowledge into interconnected schemata to utilize it effectively. The following two sections underscore the significance of English language proficiency and describe specific personality traits of successful EFL teachers. These attributes are both essential for the making of successful ESL/EFL teachers, as they enable such teachers to function effectively in their English classrooms. The final section examines further related key variables that characterize successful ESL/EFL teachers.

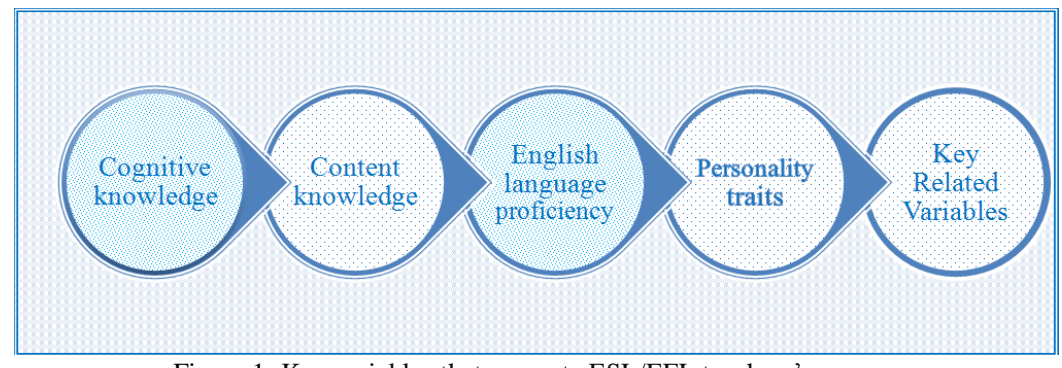

Figure 1. Key variables that promote ESL/EFL teachers' success. 


\section{ESL/EFL TEACHERS’ COGNITIVE AwARENESS OF THEIR SUCCESS}

Teachers' cognition plays a pivotal role in their lives and is a key theme in the field of language teaching. In practice, this factor concerns the unobservable cognitive dimension of language teaching, particularly what ESL/EFL teachers know, believe, and think in relation to topics relevant to language teaching as well as the relationship of these constructs to their instructional activities (Borg, 2003). In other words, teacher cognition concerns internal frames of reference, or the inner landscapes of action that teachers bring to their classroom practices; these, in turn, illuminate the hidden dynamics of ESL/EFL teachers' instructional practices and reflect the rich tapestry of their mental lives (Kubanyiova, 2015). In successful EFL language teaching, a teacher's cognition contributes to improved instructional performance and promotes the accomplishment of professional tasks. Thus, EFL teachers' cognitive knowledge- or the hidden dimensions of language teaching-is particularly important; according to Nahrkhalaji (2014), without cognitive knowledge, EFL teaching is simply a routine habit or a process of trial and error.

This section explores successful ESL/EFL teachers' explicit awareness of their cognitive knowledge, which reveals not only their actions but also what they think and do in the arena of their English classrooms. Overall, this section articulates teachers' cognitive activity and underlying mental reorientations to demonstrate the way in which their cognition is structured and how teachers apply their cognition occurs in situ, with the ultimate goal of demonstrating how one can conceptualize ESL/EFL teachers' cognition in relation to practice and how cognition informs teaching practice.

\section{Successful ESL/EFL Teachers' Cognitive Awareness of Teaching and Learning}

Successful ESL/EFL teachers' cognitive awareness lies in their recognition and practice of concerted pedagogical behaviors (classroom actions, routines, interactions, and behaviors). These behaviors represent several key constructs of cognition that form two major factors: (a) knowledge of cognition and (b) regulation of cognition, which involves regulating the teaching and learning processes precisely. In general, various networks of knowledge, thoughts, beliefs, principles, and emotions shape the cognitive knowledge that successful EFL teachers bring to their learning-to-teach experiences.

In practice, successful ESL/EFL teachers (a) hone their existing knowledge constantly; (b) construct their own conceptions and theories of language teaching and articulate personal teaching theories ; (c) familiarize themselves with new trends; and (d) reflect on the conceptualization of the teaching, beliefs, and practices in which they engage. Accordingly, successful EFL teachers demonstrate greater explicit awareness of their own cognitive knowledge, sociocultural perspectives, and assumptions regarding teaching, learning, learners, and other aspects of the profession. This awareness enables them to determine the way in which they approach teaching and thereby helps them develop their own professional knowledge and the skills necessary to be successful, which allows them to determine the ways in which they approach teaching. Successful ESL/EFL teachers also possess greater cognitive awareness of the instructional strategies and activities in their repertoire, what these entail, and when, how, and why to use them, together with ways in which to evaluate their effectiveness. This awareness enables self-regulation of teaching activities. At the same time, successful ESL/EFL teachers are conscious of any deficiencies in their skillset and recognize constraints in their professional world. As Scarino (2013) argued, language teachers' cognitions are conceptual, and the social resources and pedagogical concerns they bring to EFL instructional practice are inextricably linked. Thus, the categories of EFL teachers' cognitions meld 'together in complex and indeed inextricable ways to produce multifaceted, holistic accounts of, and actions in, language teaching" (Johnston \& Goettsch, 2000, p. 440).

\section{CONTENT KNOWLEDGE OF SuCCESSFUl EFL TEACHERS}

Successful ESL/EFL teachers also demonstrate significant ability in three central dimensions of content knowledge: disciplinary knowledge, pedagogical knowledge, and technological pedagogical knowledge. This section highlights the distinctive characteristics of each key body of knowledge.

\section{Disciplinary Knowledge}

To understand the underpinnings of their own teaching philosophy and to ensure success, successful ESL/EFL teachers continually review new sources about issues related to language acquisition. By remaining current in their field, these teachers can implement the most recent teaching methods supported by current research and thus become even more successful. This accrued knowledge is called disciplinary knowledge.

As Richards (2011) explained, disciplinary knowledge is a circumscribed body of knowledge that encompasses a much broader range of content. In this context, successful ESL/EFL teachers retain germane disciplinary knowledge that draws from various language-related milieus, including syntax, phonology, discourse analysis, applied linguistics, sociolinguistics, second-language acquisition, language learning theories, the history of language-teaching methods, principles of language learning and teaching, and culturally and linguistically responsive pedagogies, all of which enhance language learning. Successful teachers also possess a comprehensive knowledge of theories regarding the main factors and concepts of second-language learning, such as age, attitude, anxiety, motivation, language aptitude, selfefficacy, ego boundaries, affective and personality factors, and social influences.

Pedagogical Knowledge 
That said, profound disciplinary knowledge alone is not sufficient for successful ESL/EFL teaching. Successful EFL teachers also draw on strong pedagogical knowledge, or procedural knowledge, to make their instruction relevant and accessible to students. This type of knowledge falls under various categories, all of which constitute key teaching factors. Generally, however, effective pedagogical knowledge involves (a) an understanding of social, cognitive, and developmental theories of language teaching and learning, and how they apply to students in the EFL classroom; (b) knowledge of teaching processes and learning practices, or methods of teaching and learning; (c) a thorough understanding of the ways in which EFL students construct knowledge and acquire language-related skills; and (d) skills and experience in classroom management, lesson plan development and implementation, and student evaluation.

\section{Key Teaching Factors}

Methods and Approaches in EFL Teaching. Successful EFL teachers have a firm grasp on methods of and approaches to teaching the elements of language. Such pedagogical content knowledge includes knowledge of existing language-teaching methods (particularly modern methods), types of language testing, testing techniques, and the strategies used to teach language elements, including culture, grammar, vocabulary, and the four macro skills, that is, listening, speaking, reading, and writing. Successful ESL/EFL teachers also possess vast experience in curriculum planning, task and material design, evaluation, adaptation, and implementation. As Al-Mahrooqi, Denman, and AlSiyabi (2015) argued, understanding these categories of pedagogical content knowledge enhances EFL teachers' success.

Because of their strong pedagogical content knowledge, successful EFL teachers are knowledgeable about the key factors of effective language teaching, including clear directions, time management, reflective teaching, awareness of students' needs, the roles of teachers and learners, and classroom interaction and management, as well as other alternative factors. This knowledge enables them to combine some of the best aspects of more "traditional" teaching with recent innovative procedures that involve task-based and learner-centered interactive methods as well as languageteaching innovations such as participatory language teaching, sheltered language instruction, and authentic assessments. Therefore, rather than simply studying teaching techniques that involve applying quick fixes to issues that may arise, successful EFL teachers develop a much broader base of pedagogical knowledge (Loughran, 2006).

Instructional techniques. In particular, successful ESL/EFL teachers are familiar with a large repertoire of teaching techniques and can adapt and employ a myriad of judicious techniques in the classroom. These instructional techniques include classroom activities and procedures that employ specific strategies to achieve objectives, such as opening the lesson, introducing and explaining tasks, setting up learning arrangements, checking students' understanding, guiding student practice, and transitioning from one task to another (Richards, 2011).

To enhance their success in the ESL/EFL classroom and help learners acquire the desired mastery of English, successful ESL/EFL teachers implement appropriate teaching techniques and activities that vary in type and modality, and they move from more controlled to less structured activities. They select proven instructional techniques, apply sound principles of language-learning and teaching theory in designing and delivering instructional practices, and teach language concepts through a variety of modalities. Furthermore, these teachers employ a variety of instructional methods to accommodate learners' diverse abilities and learning styles, organize their instruction to provide all students the opportunity to learn, and monitor students' progress and potential. As Yazdanpanah (2015) explained, these instructional techniques are "integrated in nature rather than discrete, not allowing us to draw clear-cut borderlines between them by separating them into distinct categories" (p. 20).

Lesson plans. The ability to design and execute an effective lesson plan is also essential to effective teaching. Successful EFL teachers excel at clarifying the educational goals of each lesson and designing classroom activities and rich language-learning tasks that contribute to the realization of lesson objectives. In particular, these classroom activities address specific aspects of student learning and skills, measured in terms of students' abilities - that is, what students are able to do through instruction. In these ways, successful EFL teachers tailor their lesson plans to the needs and abilities of their students.

Moreover, successful ESL/EFL teachers ensure that activities proceed as planned, and they identify and secure the materials and equipment required beforehand. They plan for multiple elements involved in lesson planning and lesson enactment, such as structuring, pacing, and sequencing the lesson to ensure that adequate time is allotted to address each part of the lesson. At the same time, they monitor students' work, gauge its difficulty to ensure that the students are able to perform the activities, and ensure that decisions about grouping arrangements are appropriate. Finally, they use assessment before, during, and after lessons, and they delineate the critical components of differentiated instruction clearly. Above all, as language lessons are "dynamic in nature, to some extent unpredictable, and characterized by constant change" (Richards \& Lockhart, 2007), successful EFL teachers make continual interactive decisions that are appropriate to the specific dynamics of the lesson they are teaching.

\section{English Classroom Management}

A further distinctive characteristic of successful ESL/EFL teachers is their ability to effectively manage their classrooms - particularly the English learning that takes place in EFL classrooms. Successful EFL teachers are aware of the importance of classroom management, in that it maintains discipline, maximizes the available class time, and promotes comfort, order, and appropriate student behaviors. Accordingly, they develop routines, exercise proactive discipline, and maintain momentum and interest based on the age of their students, the physical environment, and the 
purpose of the instruction. To this end, they use independent work, small-group and interest-group conversations, and student-led drills appropriately to contribute to the smooth functioning of a class. Successful ESL/EFL teachers know that students who are actively involved in a class that is set at their linguistic level and incorporates their interests and backgrounds will be so busy learning that discipline will, in large measure, not be an issue.

According to Yazdanmehr and Akbari (2015), successful EFL teachers employ various management skills in the EFL classroom, including establishing rules and routines, monitoring student behavior, using preventive management strategies, and clarifying expectations so they are less opaque to students. Gatbonton (2008) noted two additional management skills: procedure checks, which involve ensuring that the lesson flows smoothly from beginning to end, and progress reviews, which ensure that students are on task and demonstrating progress. Overall, the ability to manage and organize an ESL/EFL classroom improves the probability of success in implementing teaching plans and addressing the ultimate goal: high students' performance and achievement.

\section{English Classroom Atmosphere}

Successful EFL teachers also recognize that classroom-management skills are especially important in the EFL context because EFL classrooms are extremely complex. EFL teachers need to make moment-by-moment decisions to translate a plan into action while maintaining a convivial and constructive atmosphere that facilitates language learning. In particular, students in ESL/EFL classrooms learn through their second language rather than their primary language, and thus approach all aspects of reading, writing, listening, and speaking in a language that is not their native tongue. Accordingly, students need to know that their EFL teacher supports them in this challenge and is doing his or her best to help them learn effectively while increasing their proficiency level. At the same time, EFL teachers need to demonstrate that each member of the class deserves attention, whatever his or her level of achievement, and that all students are equal in the teacher's eyes, by providing equal opportunities to participate and receive adequate feedback. In other words, EFL teachers need to establish supportive learning communities that encourage a low affective filter.

As EFL students learn best when they study in a caring, welcoming, and nonintimidating learning environment, successful EFL teachers create a friendly atmosphere in which students are free to express themselves without fear of being embarrassed in front of their peers when they err, and without fear of their teachers' contempt or criticism. Successful teachers are aware that learners need a safe and orderly learning environment that is also exciting and engaging and allows them to take risks. In such an atmosphere, students become self-motivated; they participate actively in the learning process and feel encouraged to delve into the nuances of orchestrating meaningful classroom discussions.

\section{Technological Pedagogical Knowledge}

The third body of knowledge that successful ESL/EFL teachers demonstrate is technological pedagogical knowledge: knowing how to teach ESL/EFL with technology in a way that exploits all available tools and teaching resources effectively based on the fundamental understanding that constructive use of current technologies supports ESL/EFL instruction. On this note, Koçoğlu (2009) and Chai, Chin, Koh, and Tan (2013) found that successful ESL/EFL teachers are knowledgeable about various digital technologies, aware of the effective uses of technology as pedagogical tools, and capable of incorporating varied technological applications into their EFL classrooms. Thus, successful ESL/EFL teachers possess sufficient technological pedagogical knowledge and skills as well as the ability to integrate technology effectively into the process of ESL/EFL teaching and effectively and meaningful merge technology with instructional practices and technology-enhanced classroom activities.

Technological knowledge. In particular, successful ESL/EFL teachers know which technological tools to use, how to use them appropriately, why they are important, and how English learners access and process digital information. They have a deep understanding of the affordances and constraints of technological advances and various digital technologies, and they remain abreast of the rapid advances in technology. Successful ESL/EFL teachers use this technology-related knowledge to inform effective teaching approaches, by matching technology to specific instructional goals and pedagogy, and incorporate technology effectively into the ESL/EFL classroom. Furthermore, they develop the skills necessary to look beyond the most common uses of technology and reconfigure it for customized pedagogical language teaching and learning. Accordingly, a technological knowledge base is key to successful ESL/EFL teaching (Kurt, Mishra, \& Koçoğlu, 2013).

Technological skills. Successful EFL teachers also master various technological skills that enable them to use technology to enhance their approach to teaching and learning as well as to create and implement techno-pedagogical teaching materials and activities in a real ESL/EFL classroom setting. These teachers are able to navigate technology efficiently, know how to solve technological problems, remain aware of technological developments, work with different technologies, and recognize that some tasks will soon require a high level of technological skill. Furthermore, they have an adequate understanding of and confidence in the use of various technologies, when and how to use them effectively for instructional purposes, ways to assess their use, and most importantly, ways to guide students in using high-quality technological tools to learn. Successful ESL/EFL teachers acquire these skills through continual experience with using the tools and programs available today. This experience enables them to determine whether specific technologies are suitable for students with different levels of proficiency, provide targeted support in a necessary skill, increase EFL learners' engagement and excitement, and facilitate the development of EFL skills in particular and language acquisition in general. 
Technological integration. By using this knowledge base, successful ESL/EFL teachers integrate current technological resources and applications into the EFL classroom effectively, not only at the surface level but also throughout the process of teaching and learning in ways that produce maximum language-learning outcomes. They also incorporate technology at each stage of instruction: at planning, lesson delivery, practice and review, and assessment. According to DelliCarpini (2012), integrating - or interweaving - technology into teaching and EFL lesson and unit planning is critical to ensure equitable access to and participation in the types of 21 st-century language skills required in our increasingly technological society.

\section{LANGUAGE Proficiency of SuCCESSFul ESL/EFL TEACHERS}

Although strong cognitive awareness and content knowledge are important attributes of successful EFL teachers, according to Butler (2004) and Çetinavcı and Yavuz (2011), high English language proficiency is, unsurprisingly, the most essential characteristic of a successful ESL/EFL teacher. Smadi (2013) also found an association between higher levels of English language proficiency and higher quality of instruction. Accordingly, given its primary role in EFL teaching, language proficiency is a key trait that, once achieved, leads to increased efficacy in the English-teaching process.

Unsurprisingly, successful EFL teachers demonstrate a high level of competence in and understanding of the English language system. This competence entails a declarative knowledge of English that comprises multiple constructs, including rule-governed structures, knowledge of and the ability to use English, and sociolinguistic and strategic aspects of proficiency, as well as a mastery of discourse. Successful EFL teachers also display fluency in speaking, writing, listening to, and reading English as well as expressive abilities in terms of understanding verbal and nonverbal expressions, such that they generally employ language clearly and efficiently. Finally, successful EFL teachers demonstrate the four aspects of language competence suggested by Canale and Swain (1980), as shown in Figure 2: (a) linguistics competence (explicit knowledge of language elements, such as phonology, morphology, syntax, and grammar); (b) sociocultural competence (the social and cultural rules underlying language); (c) strategic competence (the strategies used to overcome language difficulties or enhance communication); and (d) discourse competence (the forms of discourse and conventional use of communication structures).

In the EFL classroom, teachers who demonstrate high English language proficiency or reach a threshold proficiency level in English are able to provide the rich input that students need for successful language acquisition. On this note, successful EFL teachers (a) provide input at an appropriate level of difficulty, (b) maintain use of the target language in the classroom, (c) give correct feedback on learners' language, (d) personalize lessons according to students' backgrounds, (e) use a wide range of appropriate vocabulary to accomplish tasks, and (f) provide good language models. Accordingly, proficient ESL/EFL teachers are able to teach more efficiently in a variety of teaching contexts, and at all levels, as well as execute more effective lesson planning (Llurda, 2006).

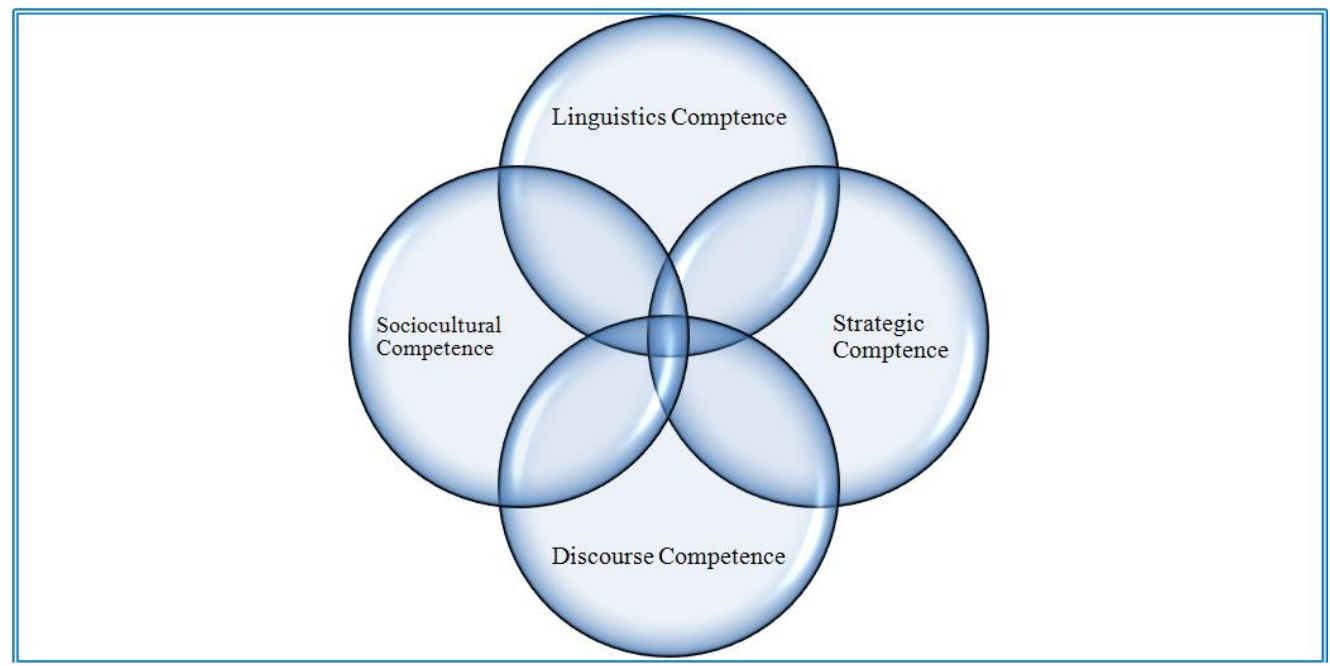

Figure 2. Four major aspects of language competence.

\section{Personal Traits of SuCCESSFul ESL/EFL TEACHERS}

Finally, successful EFL teachers demonstrate a wealth of personality traits (or "soft" attributes) with broad appeal, the most important of which are flexibility and adaptability, enthusiasm, fairness, high expectations, a good sense of humor, patience, responsibility, agreeableness, a caring attitude, friendliness, honesty, and respectfulness. These traits are related to various interpersonal dimensions of an EFL teacher's personality that are key to success in EFL teaching. In discussing five significant interpersonal dimensions that promote the mission and vision of successful EFL teaching 
and learning, this section (a) introduces the behaviors of a successful ESL/EFL teacher, (b) articulates the common principles of these behaviors (together with various correlated and more specific primary factors), and (c) sheds light on the instructional effects of these traits. Although the attributes discussed here do not encompass every major characteristic of successful EFL instructors, they are the most salient.

Flexibility and Adaptability

To teach ESL/EFL successfully, ESL/EFL teachers must first possess two crucial characteristics: flexibility and adaptability. In the EFL classroom, teachers need to adapt their instruction to their students, who, in turn, adapt to the different modes of instruction they receive. ESL/EFL teachers also need to be flexible, as both language learning and language teaching are dynamic processes in which numerous factors interplay and are susceptible to change. Moreover, no method or even combination of practices offers a panacea for EFL teaching. Instead, successful ESL/EFL teachers can accommodate various learning styles, educational backgrounds, and potentially frustrating language barriers by maintaining a flexible teaching philosophy and adapting their techniques to their students' level, culture, and goals to thereby respond to learners' specific abilities and needs.

In practice, successful EFL teachers embrace (or at least recognize) new developments in the teaching field and learn and strive constantly to evolve their understanding in response to changes in areas such as student characteristics, curricula, and teaching circumstances. Furthermore, successful EFL teachers demonstrate the willingness and ability to experiment with different teaching methods, use a variety of classroom activities, seek new ideas, and develop effective rules to manage classroom behaviors in particular settings. Successful ESL/EFL teachers also reflect on their personal experiences and adjust their methods based on emerging situations. To determine what works best, these teachers test different techniques and approaches as well as access rich, organized, and integrated knowledge from different domains flexibly, which are practices that produce greater success in student language-learning experiences.

Clearly, flexibility and adaptability are significant traits in successful EFL teaching. Accordingly, Shishavan and Sadeghi (2009) contended that successful EFL teachers also change and develop throughout their teaching career. Therefore, practitioners should view ESL/EFL teachers' success as fluid rather than fixed.

\section{Agreeableness}

In addition to flexibility and adaptability, successful EFL teachers display agreeableness. English teachers' success is perceived to exist as a consequence of their agreeable traits. ESL/EFL teachers with high levels of agreeableness tend to be cooperative, caring, good-natured, courteous, and trusting. These teachers are prosocial and adopt a communal orientation toward others. Thus, they demonstrate genuine concern and empathy toward their students.

Such interpersonal traits enhance ESL/EFL teachers' commitment and responsibility toward their students, influence their management of student learning, and enable them to create a conducive and welcoming learning environment that promotes enthusiasm and motivation. Correspondingly, their students often develop greater curiosity about the language being taught. This curiosity fosters students' desire to learn English and maintains an effective learning environment. Thus, as Badawood (2015) argued, an EFL teacher's agreeableness enhances the complexities of ESL/ EFL teaching and learning and prompts better instruction, positive learning experiences, and productive language learning.

\section{Patience and Passion}

An EFL teacher's level of flexibility and agreeableness often reflects two equally vital personal traits: patience, or pedagogical composure, and passion. These traits inform certain classroom behaviors among successful EFL teachers. First, successful ESL/EFL teachers are unhurried, calm, and difficult to unnerve; they react competently and without emotion, and exhibit a great deal of patience while explaining subject matter, thereby giving students sufficient time to internalize the particular point being studied. Second, successful EFL teachers enjoy their work wholeheartedly, are committed to their students, demonstrate an enthusiasm for teaching English, and make continual efforts to discover new and creative ways to immerse their students in language learning. In doing so, ESL/EFL teachers encourage their students to develop a passion for English and become better learners. Finally, successful EFL teachers display passion for the various cultures their students represent and celebrate this diversity. These classroom behaviors require strong degrees of both patience and passion (Korkmaz \& Yavuz, 2011).

Armed with these traits, successful English teachers tend to maintain classroom dynamics that include excitement and enjoyment. They relish their job, have a strong desire to educate, and regard their work as important. Successful ESL/EFL teachers also recognize that students find it difficult to be excited and passionate about learning if their instructors are not. Thus, teachers draw upon and apply their internal resources to bring personal excitement and passion into the classroom and connect their own personal experiences and passions with their teaching. This motivates students to take responsibility for their own learning, maximizes their participation and contributions in the classroom, and encourages them to seize all opportunities to take active roles in class activities. In this process, successful EFL teachers act as guides, facilitators, and resources - not as authoritative figures.

Overall, successful ESL/EFL teachers realize that bringing their personal strengths, interests, and passions into their teaching inspires both their students and themselves. According to Ghasemi and Hashemi (2011), such characteristics carry great significance for students because doing so arouses students' interest in learning English and helps them build self-confidence and motivation. Thus, as Ghasemi and Hashemi argued, the most effective and successful EFL teachers are passionate about their chosen profession.

Tolerance 
Patience and passion also require a certain level of tolerance, which is another essential personal quality of successful ESL/EFL teachers. As Chen and Lin (2009) asserted, tolerance concerns the degree to which EFL teachers achieve their desired effect on students while ensuring a comfortable and stimulating language-learning environment. Given the nature of foreign-language learning, EFL learners need to believe their mistakes will be tolerated and teachers will understand that progress may be slow, as moving from one stage of language learning to another takes time. Accordingly, successful ESL/EFL teachers create stress-free environments and are not easily discouraged when students do not apply what they have been taught accurately. These teachers support students with different learning speeds patiently and respond to students' questions and requests to slow the pace of lessons. In other words, successful EFL teachers acknowledge their students are learning a new language and are not yet fully competent in it; therefore, they are more tolerant and accepting of students' linguistic errors, and judicious in correcting mistakes.

In the classroom, successful ESL/EFL teachers tolerate student errors and go the extra mile to help those who are hesitant to express themselves for fear of looking foolish as well as those eager to express themselves but are unmindful of their errors. These teachers help students to achieve their potential by encouraging them to use what they have learned, recognizing and appreciating their efforts, and making them feel safe and confident when attempting new tasks. Moreover, successful EFL teachers make students feel valued and comfortable when using the language in the classroom, especially in the early stages of EFL learning, thereby maximizing student involvement.

\section{A Caring Attitude}

A positive, caring attitude is the fifth and final dimension of a teacher's personality that is key to success in EFL teaching and exemplifies the characteristics of successful EFL teachers. According to Çelik, Aarikan, and Caner (2013), a caring attitude is a leading quality of successful and effective EFL teachers because a teacher's attitude influences his or her students' success. Thus, Çubukçu (2010) stated that successful EFL teachers embrace a caring attitude toward EFL learners and their experiences. As teaching is a caring exercise, successful ESL/EFL teachers are confident that their students can learn another language and express this confidence in their students' language abilities. Students become extremely positive toward learning when teachers are fully cognizant of and believe in their students' abilities.

Furthermore, successful ESL/EFL teachers are distinctly conscious of their covert attitudes toward their students' efforts to learn English as well as the ways in which these attitudes might influence their students' learning experiences and engagement. By consciously maintaining a caring attitude, teachers can affect their students' attitudes about EFL learning positively, improve their students' self-perceptions, and optimize a range of desirable language learning outcomes. In particular, because such instructional behavior maintains students' attention, encourages active participation and engagement in the language learning process, and positively influences both the quantity and quality of students' language-learning experiences, an EFL teacher's positive attitude is effective in promoting students' productive language learning (Lee, 2010).

The ESL/EFL classroom can be a daunting place for students. To ensure successful language learning, EFL teachers should focus on developing the five interpersonal dimensions of their teaching persona discussed here: flexibility and adaptability, agreeableness, patience and passion, tolerance, and a caring attitude. By embracing these traits, ESL/EFL teachers can create a positive and encouraging language-learning environment in which students with various skillsets and backgrounds can learn and thrive.

\section{RELATED KEY VARIABLES}

As shown in Figure 3, the secrets to success in ESL/EFL teaching also lie within four general areas: (a) being involved and current in the field, (b) using effective instructional techniques, (c) undertaking individual initiatives, and (d) addressing various affective factors related to teaching.

First and foremost, there is a loose connection between success and remaining informed about recent issues in the ESL/EFL profession while being actively involved in related activities. In this case, success requires engagement in both formal and informal opportunities and experiences. Formal experiences include studying overseas; collaborating with university-based researchers; closely examining and analyzing one's own classroom practices; participating in mentorship programs under the leadership of experienced senior development professionals; attending professional meetings as well as local, regional, or international conferences that help teachers to disseminate updated information about trends in the field and enhance teachers' self-efficacy; and attending workshops on key factors in effective teaching, such as classroom management, alternative approaches, the roles of teachers and learners, and ways to combine the best aspects of "traditional" teaching with innovative procedures such as task-based, learner-centered, and interactive methods as well as participatory language teaching, sheltered language instruction, and authentic assessments. ESL/EFL teachers can also take advantage of the various growth opportunities available through online seminars, distance education, audio and video conferencing, digital conferences, asynchronous and synchronous communications, threaded discussions with colleagues and experts, and online EFL professional development programs. Exposure to such technological advances equips ESL/EFL teachers with the skills and technological and pedagogical content knowledge needed to exploit computer-based teaching resources and thereby use online and offline computer application tools more effectively in the classroom.

Informal or self-directed learning experiences may include a wide range of professional practices such as volunteering with professional organizations, reading and responding to professional publications, submitting book 
reviews, and engaging in method-neutral techniques such as dialog journals, long-distance collaboration, and study groups with fellow teachers to exchange instructional information regarding course planning, test development, and materials exploitation. Such experiences also promote competence in the type of classroom language ESL/EFL teachers should use to explain and instruct, conduct classroom activities, provide correct feedback on learners' language, and elicit ideas and contributions from students. As several contributors noted in their stories, language proficiency is a key trait that, once owned, increases the efficacy of teaching English.

Second, teaching and learning in the ESL/EFL classroom should not focus on teacher-centered knowledge transmission, with which teachers dominate classroom interactions and students receive little opportunity for input. Adherence to such models counteracts any attempt to shift the English-teaching paradigm to one that is student centered. Instead of exercising complete control of the classroom, a successful EFL teacher facilitates, takes a communicative approach, and employs less restrictive teaching methods, becoming a manager of language-learning situations rather than a material presenter and content demonstrator.

Third, best-practice initiatives are influential dimensions of ESL/EFL teachers' success. In fact, the ability for a teacher to construct and sustain successful professional practice over time through a wide range of self-initiated instructional practices and classroom behaviors is grounded in different aspects of what he or she knows, does, and learns from doing as well as day-to-day experiences such as group-based activities and participation in online professional communities. Particularly effective individual initiatives include presenting at conferences, observing fellow EFL teachers, pairing up with more experienced ESL/EFL teachers, and engaging in ongoing development practices such as self-regulation, belief monitoring, sustained motivation, critical incident analysis, and online language teaching enrollment. ESL/EFL teachers should also continually collaborate within the work context, reflect on and analyze their own practices, develop new insights into pedagogy, and explore new understandings of content resources and advanced uses of technology. Such self-initiatives contribute to the overall professional strength and success of ESL/EFL teachers and encourage the mastery of various domains of EFL language learning and teaching.

Finally, carefully considering related affective factors in the classroom - that is, various dimensions of instructional strategies, classroom management, and student engagement - is important. In particular, ESL/EFL teachers achieve success by focusing on key factors involved in promoting learners' autonomy, creating a caring classroom climate, providing learners with ample practice opportunities, and providing informative feedback. Four additional factors of success include providing adequate instruction, organizing and managing the classroom, structuring instructional material effectively, creating conditions that facilitate learning, and assimilating and accommodating new understandings.

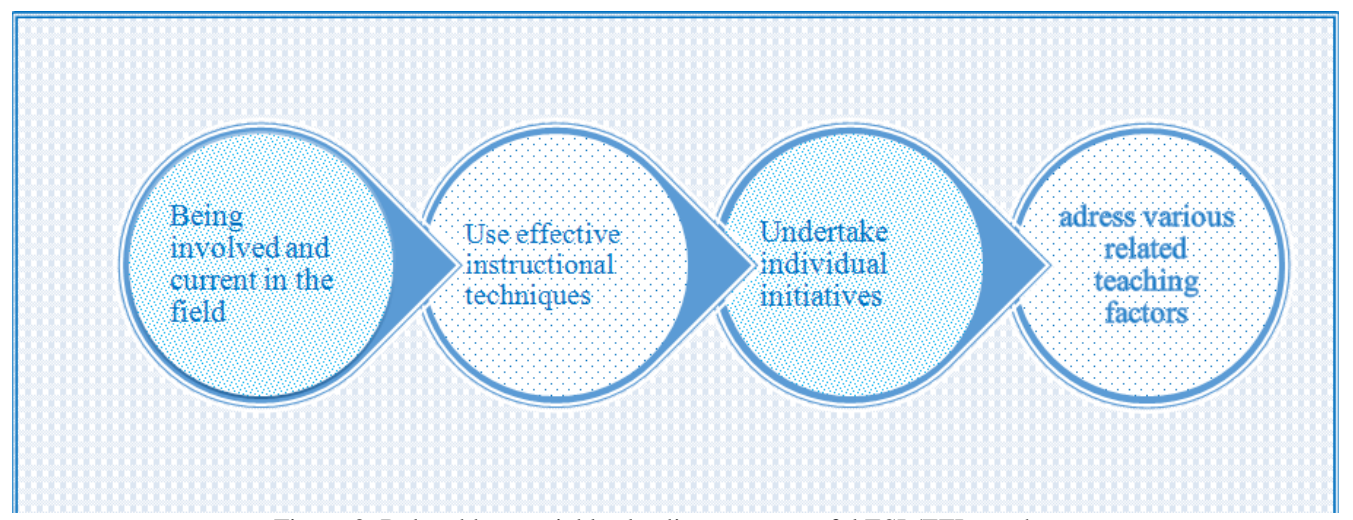

Figure 3. Related key variables leading to successful ESL/EFL teachers.

\section{CONCLUSION}

This comprehensive account provides a glimpse of numerous characteristics of successful effective ESL/EFL teachers from various angles embedded within five central dimensions, along with their underlying structures. In particular, this in-depth description and discussion of the multidimensional attributes or characteristics of successful ESL/EFL teachers illustrates that to achieve success in teaching English, ESL/EFL teachers have to be aware of and possess certain essential competencies with broad appeal across a range of domains. The identified characteristics deemed necessary for effective ESL/EFL teachers to lessen the problems and difficulties hindering ESL/EFL learners' long-lasting learning process and those needed for successful and better language teaching and learning overall are classified into categories. These categories of characteristics, under five headings, include the cognitive knowledge dimension of language teaching, sound disciplinary knowledge of related content, profound knowledge of pedagogy and technological pedagogical knowledge, high English language proficiency, and a set of attractive personal characteristics or some essential inner qualities of a teacher as well as other related key variables. ESL/EFL teachers should have a balanced combination of these five main characteristics. 
The identified central characteristics of successful ESL/EFL teachers can be maintained and enhanced through individual initiatives and efforts, adequate teacher training programs for ESL/EFL teachers, and the provision of ongoing support and professional development opportunities. These characteristics are within the grasp of most teachers and should not be overlooked. Some of them do not involve teaching techniques that require training but rather awareness, and some are gained through experience. Experience, however, requires teachers to continually engage in self-reflection and modify their classroom techniques to better serve the needs of their ESL/EFL learners. ESL/EFL teacher-preparation programs should be oriented more toward L2 acquisition theories, teaching methods, command of language skills, language improvement, and testing than toward linguistics and English literature to prepare knowledgeable and competent English teachers linguistically and pedagogically as well as facilitate their professional growth throughout their mammoth teaching journeys. In particular, fewer literature courses should be offered, and the number of methods courses for English teaching should be increased. There should also be a greater emphasis on developing the communicative competence of prospective English teachers during their college careers and linking them to schools where they can gain more experience and learn from in-service teachers.

\section{REFERENCES}

[1] Al-Mahrooqi, R. Denman, C. \& Al-Siyabi, J. (2105). Characteristics of a Good EFL Teacher: Omani EFL Teacher and Student Perspectives. Retrieved from http://sgo.sagepub.com/content/spsgo/5/2/2158244015584782.full.pdf.

[2] Badawood, O. (2015). The features of effective English teachers as viewed by English language teachers and high school students in Saudi Arabia. International Journal of English Language and Linguistics Research, 3 (6), 26-34.

[3] Borg, S. (2003). Teacher cognition in language teaching: A review of research on what language teachers think, know, believe, and do. Language Teaching, 36 (2), 81-109.

[4] Butler, Y. (2004). What level of English proficiency do elementary school teachers need to attain to Teach EFL? Case studies from Korea, Taiwan, and Japan. TESOL Quarterly, 38, (2), 245-278.

[5] Canale, M. and Merrill, M. (1980). Theoretical bases of communicative approaches to second language teaching and testing. Applied Linguistics, 1, (1), 1-47.

[6] Chai, C. Chin, C., Koh, J, and Tan, C. (2013). Exploring singaporean Chinese language teachers' technological pedagogical content knowledge and its relationship to the teachers' pedagogical beliefs. The Asia-Pacific Education Researcher, 22, (4), 657-666.

[7] Chen, Y. J., \& Lin, S. C. (2009). Exploring characteristics for effective EFL teachers from the perceptions of junior high school students in Tainan. STUT Journal of Humanities and Social Sciences, 2, (2), 219-249.

[8] ÇeLik, S., Aarikan, A., \& Caner, M. (2013). In the eyes of Turkish EFL learners: What makes an effective foreign language teacher? Porta Linguarum, 20, 287-297.

[9] Çetinavc1, U. \& Yavuz, A. (2011). Language pproficiency level of English language teacher trainees in Turkey. The International Journal of Research in Teacher Education. 1, 26-54.

[10] Çubukcu, F. (2010). Student teachers' perceptions of teacher competence and their attributions for success and failure in learning. The Journal of International Social Research, 3 (10), 213-217.

[11] DelliCarpini, L. (2012). Building computer technology skills in TESOL teacher education. Language Learning \& Technology, $16,(2), 14-23$.

[12] Gatbonton, E (2008). Looking beyond teachers' classroom behavior: Novice and experienced ESL teachers' pedagogical knowledge. Language Teaching Researchm, 12 (2), 161-182.

[13] Ghasemi, B., \& Hashemi, M. (2011). The study of the characteristics of successful English language teachers from the view point of the English language students of Islamic Azad University, Hamedan Branch. Procedia-Social and Behavioral Sciences, $28,411-415$.

[14] Gokce, K., Mishra, P., Kocoglu, Z. (2013). Technological Pedagogical Content Knowledge Development of Turkish Preservice Teachers of English. Retrieved from http://academicexperts.org/conf/site/2013/papers/38476/.

[15] Johnston, B., \& Goettsch, K. (2000). In search of the knowledge base of language teaching: Explanations by experienced teachers. Canadian Modern Language Review, 56, (3), 437-468.

[16] Korkmaz, Ş. Ç Yavuz, A. (2011). ELT student teachers' perspectives of an effective English teacher. Journal of Theory and Practice in Education, 7 (2), 207-229.

[17] Koçoğlu, Z. (2009). Exploring the technological pedagogical content knowledge of pre-service teachers in language education. Procedia Social and Behavioral Sciences, 1, 2734-2737.

[18] Kubanyiova, M. (2015). The role of teachers' future self guides in creating L2 development opportunities in teacher-led classroom discourse: reclaiming the relevance of language teacher cognition. The Modern Language Journal, 99 (3), $566-584$.

[19] Kurt, G., Mishra. P., Kocoglu, Z. (2013). Technological Pedagogical Content Knowledge Development of Turkish Pre-service Teachers of English. Retrieved from http://punya.educ.msu.edu/wp-content/uploads/2013/03/Kurt-Mishra-SITE2013-paper.pdf.

[20] Lee, J. (2010). The uniqueness of EFL teachers: Perceptions of Japanese learners. TESOL Journal, 1(1), 23-48.

[21] Llurda, E. (2006). Non-Native Language Teachers. Perceptions, Challenges and Contributions to the Profession. New York: Springer.

[22] Loughran, J. (2006). Developing a pedagogy of teacher education: Understanding teaching and learning about teaching. London: Falmer Press.

[23] Nahrkhalaji, S. (2014). EFL Teachers' metacognitive awareness as a predictor of their professional success. International Journal of Social, Behavioral, Educational, Economic, Business and Industrial Engineering, 8 (6), 1665-1669.

[24] Richards, J. (2011). Exploring teacher competence in language teaching. The Language Teacher, 35 (4), 3-7.

[25] Richards, J. and Lockhart, C. (2007). Reflective Teaching in Second Language Classrooms. Cambridge, United Kingdom. Cambridge University Press. 
[26] Smadi, O. (2013). Jordanian teachers' language proficiency, and experiential knowledge and their relationship to teachers' classroom practices. International Journal of Business and Social Science, 4 (11) 230-257.

[27] Scarino, A. (2013). Language assessment literacy as self-awareness: Understanding the role of interpretation in assessment and in teacher learning. Language Testing, 30, (3), 309-327.

[28] Shishavan, H., \& Sadeghi, K. (2009). Characteristics of an effective English language teacher as perceived by Iranian teachers and learners of English. English Language Teaching, 2 (4), 130-134.

[29] Yazdanmehr, E. and Akbari, R. (2115). An expert EFL teacher's class management. Iranian Journal of Language Teaching Research, 3(2), 1-13.

[30] Yazdanpanah, L. (2015). A Quantitative investigation of ESL teacher knowledge in Australia adult education. The Electronic Journal of English as a Second Language (TESL-EJ), 18 (4), 1-24.

Khalid Al-Seghayer earned his Ph.D. in Applied Linguistics from the University of Pittsburgh in 2003. His research interests include Computer-Assisted Language Learning and second language reading. He has taught English in the Kingdom of Saudi Arabia and the United States of America, and over the years, has taught a wide range of language-related subjects. His work has been published in TESOL Quarterly, Language Learning and Technology, CALL Journal, Internet TESL Journal, CALICO Journal, and CALL-EJ Online. His recent books are English Teaching in Saudi Arabia: Status, Issues, Challenges, Various Thoughts Concerning Teaching and Learning English, and The TEFL Black Box: Stories of Inspiring Successful Saudi EFL Teachers. He served as the chair-elect (2002-2003) of the EFL Interest Section in TESOL, the editor of the NNEST Newsletter in TESOL (2002-2004), the chair-elect of the Non-Native English Speakers (NNEST) in TESOL (2003-2004), and the editor of the CALL Media Software of Reading Matrix Journal (2003-2007). He was the chair of the English Department at Imam University, and at Saudi Electronic University. He serves currently as an editorial board member and reviewer for a number of journals, including Reading Matrix, TESOL Journal, CALICO Journal, Foreign Language Annuals Journal, Arab World English Journal, CALL Journal, IJCALLT Journal, and the International Journal of Applied Linguistics \& English Literature. 